uehiculis diues in the text of Petronius is the unfortunate gloss deriving from an erudite scribe. ${ }^{8}$

Warsaw University

MAGDALENA ZAWADZKA m.zawadzka@uw.edu.pl

JAN KWAPISZ

jan.kwapisz@uw.edu.pl

doi:10.1017/S0009838809990334

\footnotetext{
${ }^{8}$ We are very grateful to Rhiannon Ash, Mikolaj Szymanski, and $C Q$ 's referee for suggesting various improvements.
}

\title{
A FLOWERY MEADOW AND A HIDDEN METALEPSIS IN ACHILLES TATIUS
}

It is commonly known that Achilles Tatius' Leucippe and Clitophon is set apart from the other ancient Greek novels by its narrative technique. ${ }^{1}$ It is the only extant Greek novel in which the story is narrated by the protagonist himself. ${ }^{2}$ The novel's prologue is set in Sidon, where an anonymous narrator beholds a painting of Europa's abduction by Zeus and gives a lengthy description of it (1.1.2-13). The painting is simultaneously viewed by a young man who turns out to be Clitophon, the hero of the novel, and the two men begin a conversation about the power of eros. Clitophon is invited by the primary narrator to tell about his own experiences with eros. Once Clitophon has started his narration (1.3.1), the primary narrator never intervenes, and the frame narrative in Sidon is apparently never resumed. ${ }^{3}$

This note contributes to the wider issue of narrative structure in Achilles Tatius. I argue that Clitophon's portrayal of Leucippe at the end of the first book (1.19) contains a deliberate reference to the frame narrative and thus constitutes an example of the narratological device of metalepsis, defined by G. Genette as 'a deliberate transgression of the threshold of embedding'. ${ }^{4}$ Metalepsis, then, is the slippage between different levels of narration, or, in M. Fludernik's words, 'the move of existants or actants from any hierarchically ordered level into one above or below'. ${ }^{5}$ In

1 The novel is usually dated in the early second half of the second century A.D. See $O C D^{3}$ s.v. Achilles Tatius and E. Bowie, 'The chronology of the earlier Greek novels since B.E. Perry: revisions and precisions', Ancient Narrative 2 (2002), 47-63, at 60-1, who proposes A.D. 164 as a terminus ante quem.

2 On the uniqueness of this homodiegetic narration in the novelistic corpus, see, among others, B.P. Reardon, 'Achilles Tatius and ego-narrative', in J.R. Morgan and R. Stoneman (edd.), Greek Fiction: The Greek Novel in Context (London, 1994), 80-96.

3 On possible explanations of the absence of any return to the frame story, see I. Repath, 'Achilles Tatius' Leucippe and Cleitophon: what happened next?', CQ 55 (2005), 250-65, S. Nakatani, 'A re-examination of some structural problems in Achilles Tatius' Leucippe and Clitophon', Ancient Narrative 3 (2003), 63-81 and S. Rabau, 'Le roman d'Achille Tatius a-t-il une fin? Ou comment refermer une œuvre ouverte?', Lalies 17 (1997), 139-49.

${ }^{4}$ G. Genette, Narrative Discouse Revisited (Ithaca, NY, 1988), 88. See also the definition of metalepsis in G. Genette, Narrative Discourse: An Essay in Method (Ithaca, NY, 1980), 234-5: 'any intrusion by the extradiegetic narrator or narratee into the diegetic universe (or by diegetic characters into a metadiegetic universe, etc.), or the inverse'.

5 M. Fludernik, 'Scene shift, metalepsis, and the metaleptic mode', Style 37 (2003), 382-400, at 383. 
scholarship on Achilles Tatius, such slippages between the frame narrative and Clitophon's ego-narration have not yet been identified. Attention has been drawn, it is true, to the association of some characters in Clitophon's narration with figures in the frame narrative (for example, Leucippe's association with Europa, see below), but this is not the same as a deliberate narratorial reference to one specific element belonging to the conversational setting of the prologue. Because of the anonymous narrator's complete disappearance from the novel from 1.3.1 onwards, the frame narrative and Clitophon's embedded narration are generally assumed to be strictly separated from each other. ${ }^{6}$ And yet, Achilles Tatius is notorious for transgressing boundaries and blurring clear-cut distinctions. ${ }^{7}$ As this note points out, the borderline between the frame narrative and Clitophon's narration is blurred for a moment at 1.19.

By the end of the first book, Clitophon has fallen in love with Leucippe. He narrates to his interlocutor in Sidon that he observes her when she is walking in the garden of his house in Tyre. He compares her body with flowers and adopts metaphors comparing specific parts of her face with specific flowers:

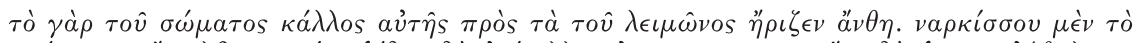

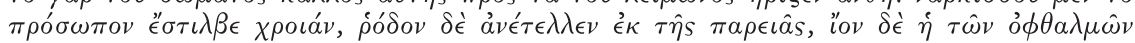

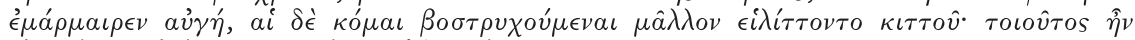

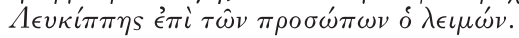

The beauty of her body challenged the flowers of the meadow: her face was the essence of pale narcissus; roses arose on her cheeks; her glance was a revelation of violet; her hair had more natural curls than spiral ivy. Such was the meadow of Leucippe's face. ${ }^{8}$

S. Bartsch identifies the comparans of this comparison ('the flowers of the meadow') as the flowers in Clitophon's garden in which the episode is set and of which the reader has been offered an extensive ecphrasis shortly before this passage (1.15.1-8). ${ }^{9}$ In her view, 'Leucippe [...] is associated with Clitophon's garden because he explicitly compares her to it at 1.19.1-3' (my italics). She points out that all four flowers with which Leucippe is compared ('the narcissus, the rose, the violet, [...] ivy') also appear in Clitophon's garden ('ivy', 1.15.3; 'violet, narcissus, rose', 1.15.5). A.R. Littlewood also assimilates Leucippe with Clitophon's garden. ${ }^{10}$ Drawing upon the erotically

${ }^{6}$ T. Whitmarsh, 'Reading for pleasure: narrative, irony, and eroticism in Achilles Tatius', in S. Panayotakis, M. Zimmerman and W. Keulen (edd.), The Ancient Novel and Beyond (Leiden, 2003), 191-205, at 193 n. 9 might well come closest to blurring the borderline between both narratorial levels when suggesting that it is not always possible to tell whether maxims in Clitophon's narrator text are focalized by Clitophon or by the anonymous ego-narrator.

7 H. Morales, Vision and Narrative in Achilles Tatius' Leucippe and Clitophon (Cambridge, 2004), 60-77 and 183, for example, identifies slippages between media within the novel. J.R. Morgan, 'Kleitophon and Encolpius: Achilleus Tatius as hidden author', in M. Paschalis, S. Frangoulidis, S.J. Harrison and M. Zimmerman (edd.), The Greek and the Roman Novel: Parallel Readings (Groningen, 2007), 105-120, for his part, reads Achilles Tatius as a hidden author who ironically communicates to the reader the improbability of some aspects of Clitophon's narration, thus blurring the borderline between authorial and narratorial representation. On the slipperiness of irony in Achilles Tatius, see also Whitmarsh (n. 6), 191-3.

8 The translation is taken from J.J. Winkler, 'Achilles Tatius, Leucippe and Clitophon', in B.P. Reardon (ed.), Collected Ancient Greek Novels² (Berkeley, Los Angeles, London, 2008), 170-284 and slightly modified where needed.

9 S. Bartsch, Decoding the Ancient Novel: The Reader and Role of Description in Heliodorus and Achilles Tatius (Princeton, 1989), 52.

10 A.R. Littlewood, 'The romantic paradise: the role of the garden in the Byzantine romance', Byzantine and Modern Greek Studies 5 (1979), 95-114, at 101-7. 
charged vocabulary in Clitophon's description of the garden, he proposes an allegorical reading of it and regards the hedges and walls as symbols for Leucippe's virginity. Bartsch (1989: 52-3), for her part, observes that the meadow on the painting in the novel's prologue is described in equally erotic vocabulary. She therefore aligns both descriptions, and argues that Leucippe is assimilated with Europa through the common imagery of the garden descriptions.

I do not doubt that Leucippe is indeed assimilated with Europa through the parallel descriptions of the vegetative settings in which both girls are depicted. However, I think that the comparisons aligning Leucippe with flowers do not only evoke Clitophon's garden. It is true that the flowers ('the narcissus, the rose, the violet, [...] ivy') also appear in Clitophon's garden and thus can be read as implicit (rather than explicit, as Bartsch would have it) markers associating Leucippe with Clitophon's garden. On the other hand, the metaphor adopted by Clitophon explicitly and repeatedly describes Leucippe's face as a 'meadow' ( $\left.\lambda \epsilon \iota \mu \omega^{\prime}, 1.19 .1-2\right)$, and not as a 'garden'. Clitophon's garden, in turn, is twice explicitly referred to as a $\pi \alpha \rho a ́ \delta \epsilon \iota \sigma o s$ (1.15.1). One would therefore expect this denomination, and not 'meadow', to figure in a metaphor that has this garden as its comparans.

What has been called a $\lambda \epsilon \iota \mu \omega ́ v$ no less than seven times, now, is the meadow on the painting of Europa and the bull in the novel's prologue (1.1.3-6). In this meadow, we admittedly do not find all four flowers appearing in Clitophon's comparison, but at least two of them (the narcissus and roses, 1.1.5). Moreover, Clitophon's narrative itself emphatically connects the term $\lambda \epsilon \iota \mu \omega \dot{v}$ to the issue of physical beauty shortly before comparing the parts of Leucippe's face with the flowers. He twice adopts this term to refer metaphorically to the beauty of a peacock, whose tail has 'a field of flowers in his feathers' ( $\lambda \epsilon \iota \mu \hat{\omega} \nu \alpha \pi \tau \epsilon \rho \hat{\omega} \nu, 1.16 .3$; $\delta$ $\tau o \hat{v} \tau \alpha \dot{\omega} \lambda \epsilon \iota \mu \omega \dot{\omega} \nu, 1.16 .3)$ that blossoms more richly than the peahen's. Since these words are part of Clitophon's embedded speech on the erotic behaviour of peacocks, intended to assimilate his own love for Leucippe with the peacock's love for the peahen (as is explicitly pointed out in 1.16.1), ${ }^{11}$ this metaphor clearly appropriates the term $\lambda \epsilon \iota \mu \omega_{\nu}$ for erotic discourse and prepares the ground for the comparison of Leucippe herself with a $\lambda \epsilon \iota \mu \omega \dot{\nu}$ shortly after. Such appropriation not only enacts a well-known literary topos, ${ }^{12}$ but also complicates Leucippe's association with the peahen by aligning her with the peacock through the common imagery of the meadow. It therefore constitutes an implicit prolepsis of her explicit comparison with the peacock a little later ( $\tau o \hat{v} \tau \alpha \hat{\omega}, 1.19 .1)$, when her beauty is said to surpass his. Since the peacock is traditionally regarded as an animal of Aphrodite, ${ }^{13}$ this twofold association further highlights the transition of the term $\lambda \epsilon \iota \mu \omega \dot{\nu}$ from the purely spatial to the erotic realm.

I suggest, then, that the meadow in Clitophon's comparison at 1.19.1 does not only refer to Clitophon's garden in which the episode is set (through the specific flowers mentioned), but that it also deliberately refers to the meadow on the painting of Europa that Clitophon himself and his interlocutor in Sidon have observed in the frame narrative. Therefore, the metaphor describing Leucippe's face as a meadow can

${ }^{11}$ On Clitophon's association with the peacock, see also H. Morales (n. 7), 185 and 190.

12 See J.M. Bremer, 'The meadow of love and two passages in Euripides' Hippolytus', Mnemosyne 28.3 (1975), 268-80, at 268-74 on the erotic implications of descriptions of flowery meadows in Greek poetry. See also A. Motte, Prairies et jardins de la Grèce antique. De la religion à la philosophie (Brussels, 1971), 9-10.

${ }_{13}$ See, for example, LIMC, s.v. Aphrodite, 46 and D. Haag-Wackernagel, Die Taube: vom heiligen Vogel der Liebesgöttin zur Strassentaube (Basel, 1998), 66 and 68-9. 
be identified as a metalepsis. The description of Leucippe's face itself is part of Clitophon's narration to his interlocutor in Sidon, but it evokes a higher narratorial level, at which the communication between the primary narrator and the narratee takes place.

This observation is important for two reasons. Firstly, it suggests an association between Leucippe and Europa through their common association with the same vegetative setting (that is, the meadow in the painting) rather than only through the parallel descriptions of the different vegetative settings at the beginning (the meadow in the painting) and the end (Clitophon's garden) of the first book, as has been argued by modern-day scholarship. Secondly, the evocation of the conversational setting in Sidon at the very end of the first book establishes a ring composition in this book and challenges any strict separation between Clitophon's narration and the frame narrative narrated by the primary narrator at Sidon. It blurs, at least for a moment, the allegedly impermeable border between narrative levels. This observation hints at the need for a more detailed study of the device of metalepsis in ancient narrative literature in general. Although Genette highlights the ancient rhetorical roots of the modern concept of metalepsis, ${ }^{14}$ most studies have explored this device only in modern and postmodern literature. ${ }^{15}$ Fludernik's recent claim that metalepsis is not an exclusively postmodernist device' but, on the contrary, has a long history, 'reaching back to the Renaissance and, possibly, to antiquity' ${ }^{16}$ illustrates particularly well where the focus of modern-day scholarship on metalepsis lies and clearly points to the lack of research into this narratological device in ancient literature. Achilles Tatius' conclusion to the first book of Leucippe and Clitophon can therefore be read as an invitation to further examine the device of metalepsis in this novel and in ancient literature in general. ${ }^{17}$

Ghent University

KOEN DE TEMMERMAN

koen.detemmerman@ugent.be doi:10.1017/S0009838809990346

${ }^{14}$ G. Genette, Métalepse (Paris, 2004), 7-14.

${ }_{15}$ See, for example, G. Genette (n. 14), B. McHale, Postmodernist Fiction (London, 1987), 112-30 and 222-7 and F. Wagner, 'Glissements et déphasages. Note sur la métalepse narrative', Poétique 130 (2002), 235-53. See also I. de Jong, 'Metalepsis in de Griekse Literatuur' (unpublished paper, Groningen, January 2008)

${ }^{16}$ M. Fludernik (n. 5), 392. D. Herman, 'Toward a formal description of narrative metalepsis', Journal of Literary Semantics 26 (1997), 132-52, at 132 also points explicitly to the primacy of postmodern literature in studies of metalepsis.

${ }^{17}$ I would like to thank Irene de Jong, Kristoffel Demoen, Jo Heirman, Graeme Miles and the anonymous referee of $C Q$ for useful comments. I also thank Graeme Miles for proofreading the manuscript. Any errors or oversights are entirely my own. 